\title{
Hubungan Aktivitas Fisik dengan Kadar Nitric Oxide (NO) Plasma pada Masyarakat di Kota Padang
}

\author{
Ghozi Natul Isral ${ }^{1}$, Afriwardi ${ }^{2}$, Delmi Sulastri ${ }^{3}$
}

\begin{abstract}
Abstrak
Nitric oxide merupakan faktor relaksan yang disentesis oleh endotel pembuluh darah yang kadarnya dapat dipengaruhi oleh aktivitas fisik. Penelitian ini bertujuan untuk mengetahui hubungan aktivitas fisik dengan kadar NO plasma pada masyarakat di kota Padang. Penelitian ini merupakan penelitian dengan data sekunder dari penelitian Delmi Sulastri dkk dalam "Pengaruh Asupan Antioksidan terhadap ekspresi Gen eNOS3 pada penderita Hipertensi Etnik Minangkabau". Subyek penelitian adalah semua responden penelitian Delmi Sulastri dkk dalam "Pengaruh Asupan Antioksidan terhadap ekspresi Gen eNOS3 pada Penderita Hipertensi Etnik Minangkabau" berjumlah 130 orang yang dinilai aktivitas fisiknya dengan menggunakan kuisioner Baecke dkk. dan dilakukan pemeriksaan kadar NO plasma. Hasil penelitian menunjukkan bahwa sebagian besar responden memiliki tingkat aktivitas fisik ringan dan NO plasma rendah dengan dengan rerata $26,3 \pm 15,2 \mu \mathrm{mol} / \mathrm{L}$. Dari analisis data didapatkan bahwa responden dengan aktivitas fisik ringan lebih banyak memiliki kadar NO plasma rendah $(61,7 \%)$ dibandingkan kadar NO plasma normal $(38,3 \%)$. Dari analisis statistik uji Chi-Square didapatkan nilai $p=0,007$ yang berarti terdapat hubungan bermakna antara aktivitas fisik dengan kadar NO plasma $(p<0,05)$. Kesimpulan penelitian ini adalah sebagian besar masyarakat di kota Padang memiliki tingkat aktivitas fisik ringan dan kadar NO plasma rendah. Dari uji statistik menunjukkan bahwa terdapat hubungan bermakna antara aktivitas fisik dengan kadar NO plasma pada masyarakat di kota Padang. Kata kunci: Aktivitas fisik, NO
\end{abstract}

\begin{abstract}
Nitric oxide is relaxan factor that is synthesized by endothelial cell of blood vessel. From previous research showed that plasma NO level influenced by physical activity. The purpose of this study is to know correlation between physical activity with plasma NO level to Padang city people. The research is a research with secondary data by Delmi Sulastri et al., in "The Influence Of Antioksidan Intake to eNOS3 Gene Ekspression In Hypertension Patients In Minangkabau Ethnicity". Participant of this research is all participant of Delmi Sulastri et al. research in "The Influence Of Antioksidan Intake to eNOS3 Gene Ekspression In Hypertension Patients In Minangkabau Ethnicity" with 130 participant. All participant were observed their physical activity using Baecke et al. quitionaire and were examined plasma NO level. Result of this study showed that most of responden have low physical activity level and low NO plasma level,with mean 26,3 $\pm 15,2 \mu \mathrm{mol} / \mathrm{L}$. From data analysis shows that subject with mild physical activity more had low plasma NO level $(61,7 \%)$ than normal plasma NO level $(38,3 \%)$. Then, from data analysis with Chi-Square test, found $p$ value $=0,007$. It mean, there is significant correlation between physical activity with NO plasma level $(p<0.05)$. The summary of this study is most of Padang city people have mild physical activity level and low NO plasma level. From data statistics analysis showed that there is significant correlation betweeen physical activity with NO plasma level to people in Padang city.
\end{abstract}

Keywords:Physical activity, NO

Affiliasi penulis : 1. Fakultas Kedokteran Universitas Andalas, 2 Bagian Fisiologi Fakultas Kedokteran Universitas Andalas. 3. Bagian Gizi Fakultas Kedokteran Universitas Andalas

Korespondensi : Ghozi Natul Isral. Email: isral fkua@yahoo.co.id Telp. 085274729713

\section{PENDAHULUAN}

Nitric Oxide (NO), sebuah molekul kecil reaktif, merupakan bioregulator penting yang luar biasa. Walaupun NO telah dikenal lebih dari 200 tahun lalu oleh Joseph Priestly, namun fungsinya sebagai biomessenger baru dikenal semenjak pertengahan tahun 1980-an. Saat ini, NO telah dikenal sebagai biomessenger yang ada di berbagai macam jenis organisme.Pada manusia, NO digunakan untuk beberapa fungsi sinyal interseluler dan intraseluler, seperti transmisi sinyal neuron, sitotoksik terhadap patogen dan tumor, koordinasi irama jantung, dan pengaturan aktivitas respirasi seluler. ${ }^{1} \mathrm{NO}$ dalam hubungannya dengan pembuluh darah dapat menyebabkan relaksasi otot polos, sehingga berfungsi sebagai regulator aliran dan tekanan darah dan mencegah agregasi dan adhesi platelet. NO juga membantu transpor oksigen dengan melebarkan dinding pembuluh darah sehingga mempermudah perpindahan gas ke jaringan dan sebaliknya. ${ }^{2}$

Sintesis NO dirangsang oleh banyak faktor, diantaranya adalah aktivitas fisik. Hasil penelitian pada hewan coba, melaporkan bahwa aktivitas fisik jangka pendek dapat menstimulasi endothelial-dependent vasodilatation.Aktivitas fisik membuat pembuluh darah terpapar dengan keadaan hiperemia yang berulang. $\mathrm{Hal}$ tersebut mengakibatkan stres pembuluh darah, sehingga terjadi vasodilatasi pembuluh darah dengan meningkatkan ekspresi nitric oxide synthase (NOS) dan melepaskan NO. Sebuah penelitian tidak terkontrol melaporkan bahwa aktivitas fisik selama enam bulan meningkatkan endothelial-dependent vasodilatation sebanyak 61 persen. Dalam penelitian lain pada pasien dengan penyakit kronik, seperti gagal jantung, diabetes melitus tipe 2, sindroma metabolik, dan hipertensi melaporkan bahwa aktivitas fisik dapat memperbaiki endothelial-dependent vasodilatation. ${ }^{3}$

Inaktivitas (kurangnya aktivitas fisik) berkaitan dengan peningkatan risiko terjadinya hipertensi (tekanan darah tinggi) dan penyakit arteri koronaria (penyumbatan arteri yang mendarahi jantung). Seseorang yang tidak aktif secara fisik, memiliki risiko $30 \%-50 \%$ lebih besar untuk mengalami hipertensi. 
Hipertensi masih menjadi masalah kesehatan di dunia dengan prevalensi yang terus meningkat. ${ }^{4}$

Berdasarkan semua fakta penelitian yang telah diuraikan diatas, perlu dilakukan penelitian untuk mengetahui hubungan aktivitas fisik dengan kadar nitric oxide (NO) plasma. Penelitian ini dilakukan di Fakultas Kedokteran Universitas Andalas dengan data sekunder dari penelitian Delmi Sulastri dkk dalam "Pengaruh Asupan Antioksidan terhadap ekspresi Gen eNOS3 pada penderita Hipertensi Etnik Minangkabau".

\section{METODE}

Jenis penelitian ini adalah penelitian dengan data sekunder dari penelitian Delmi Sulastri dkk.dalam "Pengaruh Asupan Antioksidan terhadap ekspresi Gen eNOS3 pada penderita Hipertensi Etnik Minangkabau". 5 Populasi penelitian adalah semua responden penelitian Delmi Sulastri dkk dalam "Pengaruh Asupan Antioksidan terhadap ekspresi Gen eNOS3 pada Penderita Hipertensi Etnik Minangkabau". Semua Populasi dijadikan responden penelitian.

Variabel bebas penelitian ini adalah aktivitas fisik.Aktivitas fisik adalah segala kegiatan atau aktivitas yang menyebabkan peningkatan penggunaan energi/kalori oleh tubuh.Variabel tergantung adalah nitric oxide (NO). NO adalah Gas alamiah di dalam tubuh yang dilepaskan oleh sel endotel pembuluh darah dan berperan sebagai substansi dilator umur pendekdengan kadar normal 25 - $45 \mu \mathrm{mol} / \mathrm{L}$.

Pengukuran aktivitas fisik dilakukan dengan menggunakan kuisioner Baecke dkk.yang terdiri dari indek kerja, indek olahraga dan indek waktu luang. ${ }^{6}$ Hasil indek Baecke et al. dikategorikan menjadi ringan $(\leq 6,2)$, sedang $(6,3-7,1)$, berat $(\geq 7,2)$. Kadar NO plasma diukur dengan menggunakan teknik ELISA. Kemudian nilai NO dikategorikan menjadi rendah $(<25 \mu \mathrm{mol} / \mathrm{L})$, normal $(25-45 \mu \mathrm{mol} / \mathrm{L})$, dan tinggi $(>45 \mu \mathrm{mol} / \mathrm{L})$.

Kemudian data ditabulasikan dan dilakukan analisis univariat masing-masing variabel. Hubungan aktivitas fisik dengan kadar NO plasma dianalisis dengan munggunakan uji Statistik Chi-Square test. Perbedaan dinyatakan bermakna bila $p \leq 0,05$.

HASIL

Data subyek penelitian merupakan data penelitian Delmi Sulastri dkk. dalam "Pengaruh Asupan Antioksidan terhadap ekspresi Gen eNOS3 pada Penderita Hipertensi Etnik Minangkabau" yang dilakukan di empat kecamatan di kota Padang, yaitu kecamatan Padang Utara, Padang Barat, Pauh, dan Lubuk Kilangan dengan jumlah subyek penelitian adalah 130 orang (tabel 1).65 oarang responden sehat dan 65 orang responden menderita hipertensi. Responden (sehat+hipertensi) memilki usia rerata $50,01 \pm 7,66$ tahun dengan umur terendah 32 tahun dan umur tertinggi 65 tahun. Sedangkan usia rerata responden sehat adalah 49,6 $\pm 8,03$ tahun dengan usia terendah 32 tahun dan tertinggi 65 tahun. Kemudian pada responden dengan hipertensi didapatkan rerata usia 50,41 $\pm 7,31$ tahun dengan usia terendah 33 tahun dan tertinggi 65 tahun.

Tabel 1. Karakteristik Responden

\begin{tabular}{|c|c|c|}
\hline Karakteristik responden & f & $\%$ \\
\hline $\begin{array}{l}\text { Jenis Kelamin } \\
\text { Pria } \\
\text { Wanita }\end{array}$ & $\begin{array}{c}28 \\
102\end{array}$ & $\begin{array}{l}21,5 \\
78,5\end{array}$ \\
\hline Total & 130 & 100 \\
\hline \multicolumn{3}{|l|}{ Tingkat Pendidikan } \\
\hline Tidak tamat SD & 29 & 22,3 \\
\hline Tamat SD & 29 & 22,3 \\
\hline Tamat SMP & 22 & 16,9 \\
\hline Tamat SMA & 40 & 30,8 \\
\hline Tamat Akademi/PT & 10 & 7,7 \\
\hline Total & 130 & 100 \\
\hline \multicolumn{3}{|l|}{ Pekerjaan } \\
\hline Tidak bekerja & 71 & 54,6 \\
\hline Petani & 7 & 5,4 \\
\hline Nelayan & 2 & 1,5 \\
\hline Dagang & 19 & 14,6 \\
\hline Wiraswasta & 16 & 12,3 \\
\hline ABRI & 2 & 1,5 \\
\hline PNS & 13 & 10,0 \\
\hline Total & 130 & 100 \\
\hline \multicolumn{3}{|l|}{ Status Kesehatan } \\
\hline Sehat & 65 & 50,0 \\
\hline Hipertensi & 65 & 50,0 \\
\hline Total & 130 & 100 \\
\hline
\end{tabular}

Aktivitas fisik diukur dengan kuisioner indek Baecke dkk.dan didapatkan sebagian besar responden memiliki tingkat aktivitas fisik ringan $(72,3 \%)$ (gambar 1). NO diperiksa dengan teknik ELISA dan didapatkan sebagian besar responden memiliki kadar NO plasma rendah (68,5\%) (gambar 2). Rerata kadar NO plasma adalah $26,35 \pm 15,17 \mu \mathrm{mol} / \mathrm{L}$ dengan kadar NO terendah adalah $6 \mu \mathrm{mol} / \mathrm{L}$ dan kadar tertinggi adalah $67,5 \mu \mathrm{mol} / \mathrm{L}$.(tabel 2 )

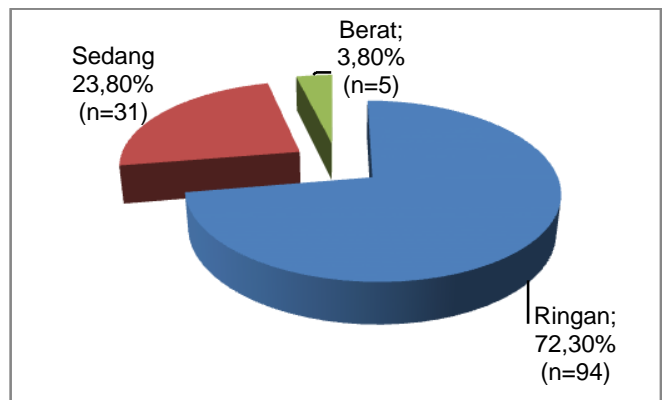

Gambar 1. Distribusi responden berdasarkan aktivitas fisik 


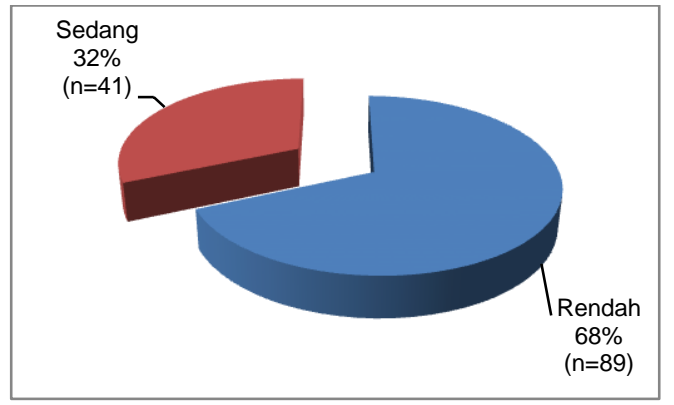

Gambar 2. Distribusi responden berdasarkan kadar NO plasma

Tabel 2. Gambaran Kadar NO responden

\begin{tabular}{|c|c|c|c|c|}
\hline & $\mathbf{n}$ & Mean士SD & Min & Max \\
\hline \multicolumn{5}{|l|}{$\begin{array}{l}\text { Status } \\
\text { kesehatan }\end{array}$} \\
\hline $\begin{array}{l}\text { Sehat }+ \\
\text { Hipertensi }\end{array}$ & 130 & $\begin{array}{c}26,35 \pm 15,17 \\
\mu \mathrm{mol} / \mathrm{L}\end{array}$ & $\begin{array}{c}6,0 \\
\mu \mathrm{mol} / \mathrm{L}\end{array}$ & $\begin{array}{c}67,5 \\
\mu \mathrm{mol} / \mathrm{L}\end{array}$ \\
\hline Sehat & 65 & $\begin{array}{c}25,78 \pm 15,03 \\
\mu \mathrm{mol} / \mathrm{L}\end{array}$ & $\begin{array}{c}9,0 \\
\mu \mathrm{mol} / \mathrm{L}\end{array}$ & $\begin{array}{r}67,5 \\
\mu \mathrm{mol} / \mathrm{L}\end{array}$ \\
\hline Hipertensi & 65 & $\begin{array}{c}26,91 \pm 15,40 \\
\mu \mathrm{mol} / \mathrm{L}\end{array}$ & $\begin{array}{c}6,0 \\
\mu \mathrm{mol} / \mathrm{L}\end{array}$ & $\begin{array}{r}66,0 \\
\mu \mathrm{mol} / \mathrm{L}\end{array}$ \\
\hline \multicolumn{5}{|l|}{ Usia } \\
\hline $32-45$ tahun & 39 & $\begin{array}{c}28,32 \pm 16,45 \\
\mu \mathrm{mol} / \mathrm{L}\end{array}$ & $\begin{array}{c}9,0 \\
\mu \mathrm{mol} / \mathrm{L}\end{array}$ & $\begin{array}{r}67,5 \\
\mu \mathrm{mol} / \mathrm{L}\end{array}$ \\
\hline $46-55$ tahun & 56 & $\begin{array}{c}26,25 \pm 15,35 \\
\mu \mathrm{mol} / \mathrm{L}\end{array}$ & $\begin{array}{c}9,0 \\
\mu \mathrm{mol} / \mathrm{L}\end{array}$ & $\begin{array}{r}66,0 \\
\mu \mathrm{mol} / \mathrm{L}\end{array}$ \\
\hline $56-65$ tahun & 35 & $\begin{array}{c}24,30 \pm 13,43 \\
\mu \mathrm{mol} / \mathrm{L}\end{array}$ & $\begin{array}{c}6,0 \\
\mu \mathrm{mol} / \mathrm{L}\end{array}$ & $\begin{array}{c}64,5 \\
\mu \mathrm{mol} / \mathrm{L}\end{array}$ \\
\hline
\end{tabular}

Tabel 3. Hasil analisis data hubungan aktivitas fisik dengan kadar NO plasma

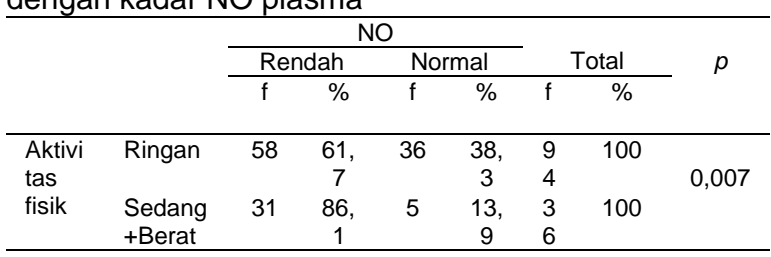

Pada analisis data disimpulkan bahwa responden dengan aktivitas fisik ringan lebih banyak memiliki kadar NO plasma rendah (61,7\%) dibandingkan kadar NO plasma normal (38,3\%). Dari hasil uji statistik menunjukkan bahwa terdapat hubungan bermakna antara aktivitas fisik dengan kadar NO plasma $(p<0,05)$.

\section{PEMBAHASAN}

\section{Keterbatasan Penelitian}

Penelitian terhadap hubungan aktivitas fisik dengan kadar NO plasma pada masyarakat di kota Padang dengan menggunakan data penelitian Delmi Sulastri, dkk. ini telah dilakukan sesuai prosedur pengolahan data yang meliputi editing, coding, entry, dan cleaning data dan analisis data. Namun, peneliti memiliki keterbatasan dalam penelitian ini.Instrumen penelitian yang digunakan untuk menilai aktivitas fisik responden adalah kuisioner Baecke dkk. Penilaian aktivitas fisik menggunakan kuisioner ini dapat mempengaruhi hasil penelitian karena penilaian berdasarkan persepsi subyek penelitian.

\section{Aktivitas Fisik}

Responden pada penelitian ini berusia antara

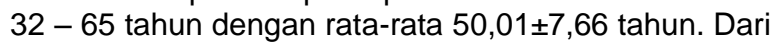
pengolahan data didapatkan $73,3 \%(n=94)$ responden memiliki tingkat aktivitas fisik ringan, 23,8\% $(n=31)$ responden memiliki tingkat aktivitas fisik sedang, dan $3,8 \%(n=5)$ responden memiliki tingkat aktivitas berat. Jadi dapat disimpulkan sebagian besar responden memiliki tingkat aktivitas fisik ringan.

Penelitian yang sama telah juga dilakukan oleh Kamso di kota Padang dengan umur rerata usia responden 64 tahun. Namun, hasil penelitiannya dilaporkan bahwa aktivitas fisik responden termasuk kategori sedang dengan metode Baecke. ${ }^{7}$ Kemudian dari data Susenas 2004 terhadap penduduk berusia $>15$ tahun di daerah perkotaan di Sumatera Barat melaporkan bahwa $29,34 \%$ penduduk memiliki aktivitas fisik berat, $72,4 \%$ memiliki aktivitas fisik sedang dan $52,6 \%$ memiliki aktivitas fisik ringan.

Perbedaan hasil penelitian disebabkan karena adanya karakteristik sampel dan metode yang digunakan untuk mengukur tingkat aktivitas fisik.Tingkat aktivitas fisik yang ringan pada responden di penelitian ini kemungkinan disebabkan karena sebagian besar responden adalah ibu rumah tangga yang digantikan oleh anak mereka melakukan pekerjaannya. Disamping itu, kemungkinan faktor usia juga mempengaruhi. Maurice dalam Pratama mengatakan bahwa kemampuan fisik seseorang mencapai puncaknya pada usia 30 tahun dan kemudian mengalami penurunan sesuai umur. ${ }^{9}$

\section{Kadar NO Plasma dan Hubungannya dengan Aktivitas Fisik}

Pada penelitian ini, dari seluruh responden (sehat+hipertensi) didapatkan 68,5\% ( $n=89)$ responden memiliki kadar NO plasma rendah dan $31,5 \%(n=41)$ responden memiliki kadar NO plasma normal. Rerata kadar NO plasma responden adalah $26,35 \pm 15,17 \mu \mathrm{mol} / \mathrm{L}$ dengan kadar $\mathrm{NO}$ terendah adalah $6 \mu \mathrm{mol} / \mathrm{L}$ dan kadar tertinggi adalah 67,5 $\mu \mathrm{mol} / \mathrm{L}$. Kemudian, pada responden yang sehat, didapatkan rerata kadar NO yaitu $25,78 \pm 15,03 \mu \mathrm{mol} / \mathrm{L}$ dengan nilai terendah $9,0 \mu \mathrm{mol} / \mathrm{L}$ dan nilai tertinggi $67,5 \mu \mathrm{mol} / \mathrm{L}$. Sedangkan pada responden dengan hipertensi, rerata kadar NO sedikit lebih tinggi dibandingkan responden yang sehat, yaitu $26,91 \pm 15,40 \mu \mathrm{mol} / \mathrm{L}$ dengan nilai terendah $6,0 \mu \mathrm{mol} / \mathrm{L}$ dan nilai tertinggi $66,0 \mu \mathrm{mol} / \mathrm{L}$. Hasil rerata $\mathrm{NO}$ pada penelitian ini sesuai dengan kadar NO plasma normal yaitu $25-45 \mu \mathrm{mol} / \mathrm{L}$ tetapi berada pada kadar normal yang rendah. Dilihat dari usia, rerata usia responden sehat dengan hipertensi hampir sama, yaitu 49,6 $\pm 8,03$ pada responden sehat dan $50,41 \pm 7,31$ tahun pada responden hipertensi.

Hasil ini berbeda dengan penelitian Abadi dalam penelitiannya terhadap 14 orang responden di Makasar dengan rerata usia $32,50 \pm 9,55$ tahun mendapatkan rerata kadar NO responden $67,59 \pm 15,50 \mu \mathrm{mol} / \mathrm{L}^{10} \mathrm{~K}^{10}$ Kemudian pada penelitian Ceylan dengan 33 orang responden dengan usia rerata 30,8 tahun bahkan memilki rerata kadar NO plasma yang jauh lebih tinggi, yaitu sebesar 109,5 $\pm 6,2$ $\mu \mathrm{mol} / \mathrm{L} .{ }^{11}$ Pada penelitian Obineche di Uni Emirat Arab terhadap 112 orang responden dengan usia 
rerata 45,6 \pm 8,6 tahun mendapatkan rerata kadar NO plasma responden sebesar 29,8 \pm 15,0 $\mu \mathrm{mol} / \mathrm{L} .{ }^{12}$ Sedangkan pada penelitian Schulz pada 18 orang responden dengan usia rerata $61 \pm 2$ tahun mendapatkan rerata kadar $\mathrm{NO}$ plasma responden $36,7 \pm 1,7 \mu \mathrm{mol} / \mathrm{L}^{13}$

Perbedaan hasil penelitian tersebut karena adanya perbedaan karakteristik sampel penelitian. Dari penelitian Abadi dan Obineche tersebut dapat dilihat bahwa kadar NO plasma responden dengan usia rerata lebih muda lebih tinggi. Kadar NO plasma yang rendah pada penelitian ini mungkin disebabkan oleh faktor usia responden dengan rerata usia yang sudah cukup tua. Usia dapat mempengaruhi kemampuan endotel untuk mensintesis NO, pada usia lanjut kemampuan endotel dalam mensintesis NO sudah mulai berkurang. Peneliti Andreas dan Tobin seperti yang dikutip oleh Martono memperkenalkan "hukum 1\%" yang menyatakan bahwa fungsi organ akan menurun sebanyak $1 \%$ setiap tahunnya setelah usia 30 tahun. Jadi, kemungkinan endotel sebagai tempat sintesis NO juga mengalami penurunan fungsi sehingga mengakibatkan penurunan kadar NO plasma.

Pada penelitian ini, rerata kadar NO plasma responden dengan hipertensi sedikit lebih tinggi dibandingkan dengan responden yang sehat, yaitu $25,78 \pm 15,03 \mu \mathrm{mol} / \mathrm{L}$ pada responden sehat dan $26,91 \pm 15,40 \mu \mathrm{mol} / \mathrm{L}$ pada responden hipertensi. Dilihat dari usia, rerata usia responden dengan hipertensi sedikit lebih tinggi dibandingkan responden normal, yaitu 50,41 $\pm 7,31$ tahun pada responden hipertensi dan $49,6 \pm 8,03$ tahun pada responden sehat.

Hasil ini berbeda dengan penelitian sebelumnya oleh Arora, dkk. pada responden hipertensi dan normotensi dengan rerata usia 46,15 \pm 5,5 tahun dan $43,0 \pm 12,8$ tahun yang melaporkan bahwa kadar NO plasma pada responden hipertensi lebih rendah dibanding responden normotensi. Pada responden hipertensi ditemukan kadar NO plasma 4,0 $\pm 1,7 \mu \mathrm{mol} / \mathrm{L}$ sedangkan pada responden normotensi $6,7 \pm 3,2 \mu \mathrm{mol} / \mathrm{L}^{15}$ Kemudian Ishaque juga melaporkan bahwa kadar NO plasma responden hipertensi lebih rendah dibanding kontrol normotensi. Pada hipertensi ditemukan kadar NO plasma $41,54 \pm 0,78 \mu \mathrm{mol} / \mathrm{L}$ sedangkan pada kontrol normotensi 45,95 $\pm 1,05 \mu \mathrm{mol} / \mathrm{L} .{ }^{16}$

Dari penelitian Arora dan Ishaqu terlihat bahwa responden dengan hipertensi memiliki kadar NO plasma yang rendah dibandingkan dengan responden normotensi. Hal itu kemungkinan disebabkan karena pada hipertensi terjadi gangguan pada endotel pembuluh darah sehingga sintesis NO berkurang. Namun pada penelitian ini, kadar NO plasma responden dengan hipertensi justru lebih tinggi dibandingkan responden sehat (normotensi). Perbedaan kadar NO plasma tersebut kemungkinan disebabkan oleh perbedaan karakteristik responden penelitian dan faktor genetik.

Namun, ada beberapa faktor yang mempengaruhi kadar NO plasma, diantaranya adalah aktivitas fisik. Hasil analisis data penelitian ini menunjukkan bahwa terdapat hubungan bermakna antara aktivitas fisik dengan kadar NO plasma. Hasil penelitian ini didukung oleh penelitian Guzel, dkk. yang melaporkan bahwa latihan fisik selama 12 minggu meningkatkan kadar NO plasma. ${ }^{17}$ Kemudian Hambrecht, dkk. dalam penelitiannya terhadap pengaruh aktivitas fisik terhadap endothelial nitric oxide synthase (eNOS) melaporkan bahwa terdapat peningkatan dua kali lipat ekspresi protein eNOS kelompok yang diberikan latihan fisik dibanding kelompok kontrol. ${ }^{18}$ Dengan meningkatnya ekspresi protein eNOS, maka kadar NO plasma juga akan mengalami peningkatan.

Kingwell dalam penelitiannya melaporkan bahwa latihan fisik pada orang sehat akan meningkatkan kadar NO plasma dengan berbagai mekanisme, termasuk dengan meningkatkan aktivitas dan ekspresi enzim NOS. ${ }^{19}$ Kemudian, pada penelitian Ignarro, dkk. melaporkan bahwa pada orang dengan gaya hidup yang sering duduk atau kurang aktivitas fisik menunjukkan kadar NO plasma yang tetap. Sedangkan pada orang yang melakukan aktivitas fisik sedang menunjukkan peningkatan kadar NO plasma dan peningkatan yang kadar $\mathrm{NO}$ yang lebih tinggi terlihat pada orang dengan aktivitas fisik berat. ${ }^{20}$ Penelitian-penelitian tersebut menunjukkan bahwa antara aktivitas fisik dan kadar NO plasma memiliki hubungan yang signifikan.

\section{KESIMPULAN}

Sebagian besar masyarakat di kota Padang memiliki tingkat aktivitas fisik ringan dan kadar NO plasma rendah. Terdapat hubungan bermakna antara aktivitas fisik dengan kadar NO plasma pada masyarakat di kota Padang

\section{DAFTAR PUSTAKA}

1. Groves JT, Wang, CY Charles. Nitric oxide synthase: model and mechanisms. Current Opinion in Chemical Biology, 2000;4:687-695. (diunduh 6 April 2013). Tersedia dari: URL: HYPERLINK http://www.ncbi.nlm.nih.gov/pubmed/11102875

2. Idhayu AT. Pengaruh pemberian polifenol teh hijau terhadap sekresi nitrit oksida (NO) sel fagosit (skripsi). Semarang. Universitas Diponegoro, 2006. (diunduh 21 Maret 2013). Tersedia dari: URL: HYPERLINK http://eprints.undip.ac.id/19116/

3. Stewart KJ, William $\mathrm{RH}$, Judith $\mathrm{GR}$, Alan $\mathrm{TH}$ Exercise training for claudication. $\mathrm{N}$ Engl $\mathrm{J}$ Med, 2002;24(347):1941-51 (diunduh 31 Maret 2013). Tersedia dari: URL: HYPERLINK http://www.nejm.org/doi/full/10.1056/NEJMra021 135

4. Dreisbach AW, Batuman V (ed). Epidemiology of hypertension. 2011. (diunduh 1 Juni 2013). Tersedia dari: URL: HYPERLINK http://emedicine.medscape.com/.../1928048overview.

5. Sulastri D, Rahmatini, Nur IL, Zulkarnain E. Pengaruh asupan antioksidan terhadap ekspresi gen eNos3 pada penderita hipertensi etnik Minangkabau (disertasi). Padang: Fakultas kedokteran Universitas Andalas; 2011.

6. Baecke JAH, Jan B, Jan ERF. A short questionnaire for the measurement of habitual physical activity in epidemiological studies. AJCN. 1982;36:936-42 (diunduh 3 Oktober 2013). Tersedia dari: URL: HYPERLINK http://ajcn.nutrition.org/content/36/5/936.full.pdf

7. Kamso S, Purwantyastuti, Ratna J. Dislipidemia pada lanjut usia di kota Padang. Makara Kesehatan, 2002;6(2):55-8 (diunduh 14 Januari 2014). Tersedia dari: URL: HYPERLINK 
http://journal.ui.ac.id/index.php/health/article/view $152 / 48$

8. Departemen Kesehatan Republik Indonesia. Profil Kesehatan Indonesia 2004. Lampiran 2.35. Jakarta: 2006 (diunduh 9 Januari 2014). Tersedia dari: URL: HYPERLINK http://www.depkes.go.id/downloads/publikasi/Prof il\%20Kesehatan\%20Indonesia\%202004.pdf

9. Pratama, IWGA. Hubungan antara aktivitas fisik dengan status gizi pada lansia wanita $60-74$ tahun di RW 02 kelurahan Depok Jaya (skripsi). Jakarta: Fakultas Kedokteran Universitas Pembangunan Nasional "Veteran"; 2012 (diunduh 7 Januari 2014). Tersedia dari: URL: HYPERLINK

http://www.library.upnvj.ac.id/pdf/5FKS1KEDOKT ERAN/0810211163/BAB\%20II.pdf.

10. Abadi AG, Yudy G, Amiruddin A, Muhammad A, Ilhamjaya $P$, Mansyur A. Perubahan kadar nitric oxide (NO) plasma selama induksi cold pressor test pada penderita migren tanpa aura fase interiktal. JST Kesehatan. 2012;2(1):1-8 (diunduh 11 januari 2014). Tersedia dari: URL: HYPERLINK

http://pasca.unhas.ac.id/jurnal/files/d9fb29d9b20 31d8cdda5560d52d9e80d.pdf.

11. Ceylan NÖ, İclal GÇ, Ayşe K, Feridun B, Haluk AS. Alterations in plasma nitric oxide level and arginase activity during the treatment of bipolar depressive episode. Journal of Mood Disorders. 2011; 1: 1-6 (diunduh 11 Januari 2014). Tersedia dari: URL: HYPERLINK http://jmood.org/pdf/ENJMOOD-35a57004.pdf.

12. Obineche EN, Abdishakur MA, Javid YP, Nico JDN. Plasma endothelin-1, homocysteine, and nitric oxide levels in a multiethnic hypertensive cohort from the United Arab Emirates. Journal of Medical Sciences, 2010; 3(3): 153-9 (diunduh 11 Januari 2014). Tersedia dari: URL: HYPERLINK http://benthamscience.com/cdtia/openaccessartic les/cdtia4-4/0008L.pdf.

13. Schulz R, D Schmidt, A Blum, X Lopes-Ribeiro, C Lücke, K Mayer, H Olschewski, W Seeger, F Grimminger. Decreased plasma levels of nitric oxide derivatives in obstructive sleep apnoea: response to CPAP therapy. Thorax, 2000; 55: 1046-51 (diunduh 11 Januari 2014). Tersedia dari: URL: HYPERLINK http://thorax.bmj.com/content/55/12/1046.full.pdf

14. Martono H. Aspek fisiologik dan patologik akibat proses menua. Dalam: Buku Ajar Geriatri.
Jakarta: Balai Penerbit Fakultas Kedokteran Universitas Indonesia; 2004. hlm.56.

15. Arora S, Nibhriti D, Kamna S. Nitric oxide and eNos gene in essential hypertension. International Journal of Collaborative Research on Internal Medicine \& Public Health, 2009;2(1): 56-71 (diunduh 28 Januari 2014). Tersedia dari: URL: HYPERLINK http://iomcworld.com/ijcrimph/files/v01-n0203.pdf.

16. Ishaque S, Aziza K. Relationship of nitric oxidewith other risk factors of hypertension. Medical Channel. 2010;4(16): 607-11 (diunduh 28 Januari 2014). Tersedia dari: URL: HYPERLINK

http://www.medicalchannel.pk/downloads/vol16/n 04/30RELETIONSHIP\%20OF\%20NITRIC\%20(D R\%20SADIA\%20ISHAQUE)\%20607-611.pdf

17. Guzel NA, Lamia P, Filiz C, Selma K, Cigdem O. Long-Term Callisthenic Exercise-related changes in blood lipids, homocysteine, nitric oxide levels and body composition in middleaged healthy sedentary women. Chinese Journal of Physiology, 2012; 55(3): $202-9$ (diunduh 17 Desember 2013). Tersedia dari: URL: HYPERLINK http://www.cps.org.tw/docs/11.\%20202-209.pdf.

18. Hambrecht $R$, Adams $V$, Erbs $S$, Linke $A$, Kränkel N, Sh Yu, et al. Regular physical activity improves endothelial function in patients with coronary artery disease by increasing phosphorylation of endothelial nitric oxide synthase. Circulation, 2003; 107: 3152-8 (diunduh 13 Januari 2014). Tersedia dari: URL: HYPERLINK

http://circ.ahajournals.org/content/107/25/3152.ful I.pdf+html.

19. Kingwell BA. Nitric oxide-mediated metabolic regulation during exercise: effects of training in health and cardiovascular disease. The Faseb Journal. 2000;14:1685-96 (diunduh 17 Desember 2013). Tersedia dari: URL: HYPERLINK http://www.fasebj.org/content/14/12/1685.full.pdf + html.

20. Ignarro LJ, Maria LB, Napoli C. Nutrition, physical activity, and cardiovascular disease: an update. Cardiovascular Research, 2007; 73: 326-40 (diunduh 13 Januari 2014). Tersedia dari: URL: HYPERLINK http://cardiovascres.oxfordjournals.org/content/73 /2/326.full.pdf+html. 